\title{
ChAT-ChR2-EYFP Mice Have Enhanced Motor Endurance But Show Deficits in Attention and Several Additional Cognitive Domains
}

\author{
Benjamin Kolisnyk, ${ }^{1,2}$ Monica S. Guzman, ${ }^{1,3}$ Sanda Raulic, ${ }^{1}$ Jue Fan, ${ }^{1}$ Ana C. Magalhães, ${ }^{1,4}$ Guoping Feng, ${ }^{6}$ \\ Robert Gros, ${ }^{1,3,5}$ Vania F. Prado, ${ }^{1,2,3,4}$ and Marco A. M. Prado ${ }^{1,2,3,4}$ \\ ${ }^{1}$ Robarts Research Institute, ${ }^{2}$ Graduate Program in Neuroscience, and Departments of ${ }^{3}$ Physiology and Pharmacology, ${ }^{4}$ Anatomy and Cell Biology, and \\ ${ }^{5}$ Medicine, Schulich School of Medicine and Dentistry, University of Western Ontario, London, Ontario, Canada N6A 5K8, and ${ }^{6} \mathrm{McGovern} \mathrm{Institute} \mathrm{for}$ \\ Brain Research, Department of Brain and Cognitive Sciences, Massachusetts Institute of Technology, Cambridge, Massachusetts 02139
}

Acetylcholine $(\mathrm{ACh})$ is an important neuromodulator in the nervous system implicated in many forms of cognitive and motor processing. Recent studies have used bacterial artificial chromosome (BAC) transgenic mice expressing channelrhodopsin-2 (ChR2) protein under the control of the choline acetyltransferase (ChAT) promoter (ChAT-ChR2-EYFP) to dissect cholinergic circuit connectivity and function using optogenetic approaches. We report that a mouse line used for this purpose also carries several copies of the vesicular acetylcholine transporter gene (VAChT), which leads to overexpression of functional VAChT and consequently increased cholinergic tone. We demonstrate that these mice have marked improvement in motor endurance. However, they also present severe cognitive deficits, including attention deficits and dysfunction in working memory and spatial memory. These results suggest that increased VAChT expression may disrupt critical steps in information processing. Our studies demonstrate that ChAT-ChR2-EYFP mice show altered cholinergic tone that fundamentally differentiates them from wild-type mice.

\section{Introduction}

Acetylcholine (ACh) has multiple functions in the CNS, including modulation of attention and memory encoding, consolidation, and retrieval (Prado et al., 2013). Understanding the precise roles of $\mathrm{ACh}$ in distinct brain regions has remained a challenge because of the myriad of cholinergic receptors that can modulate postsynaptic and presynaptic cholinergic activities (Hasselmo and Sarter, 2011). Genetic approaches have been used to determine the specific roles of ACh in different brain regions (Guzman et al., 2011; Martyn et al., 2012; Patel et al., 2012), as well as to pinpoint precise functions of ACh receptors (for review, see Wess et al., 2007; Changeux, 2010). More recently, optogenetics has also been used to further dissect and understand cholinergic signaling in the CNS (Witten et al., 2010; Nagode et al., 2011; Ren et al., 2011; Zhao et al., 2011; Gu et al., 2012). One of the approaches

Received Jan. 28, 2013; revised May 13, 2013; accepted May 16, 2013.

Author contributions: B.K., R.G., V.F.P., and M.A.M.P. designed research; B.K., M.S.G., S.R., J.F., and A.C.M. performed research; G.F. and V.F.P. contributed unpublished reagents/analytic tools; B.K., M.S.G., S.R., J.F., R.G., V.F.P., and M.A.M.P. analyzed data; B.K., V.F.P., and M.A.M.P. wrote the paper.

This work was supported by Canadian Institutes of Health Research Grants MOP 89919 and 126000 (M.A.M.P. and V.F.P.), Natural Sciences and Engineering Research Council of Canada (V.F.P.), Heart and Stroke Foundation of Ontario Grant NA 6656 (M.A.M.P., V.F.P., and R.G.), Canada Foundation for Innovation (M.A.M.P., V.F.P., and R.G.), Ontario Research Fund (M.A.M.P., V.F.P., and R.G.), and a fellowship (M.S.G.) and a New Investigator Award (R.G.) from the Heart and Stroke Foundation of Canada.

The authors declare no competing financial interests.

Correspondence should be addressed to either Marco Prado or Vania Prado, Robarts Research Institute, University of Western Ontario, 100 Perth Drive, London, Ontario, Canada N6A 5K8. E-mail: mprado@robarts.ca; vprado@robarts.ca.

DOI:10.1523/JNEUROSCI.0395-13.2013

Copyright $\odot 2013$ the authors $\quad 0270-6474 / 13 / 3310427-12 \$ 15.00 / 0$ to specifically activate cholinergic neurons using optogenetics is in vivo injection of Cre-inducible viral vectors carrying the channelrhodopsin-2 (ChR2) gene. Cholinergic specificity is ensured by using bacterial artificial chromosome (BAC) transgenic mice expressing Cre recombinase under the control of the choline acetyltransferase (ChAT) promoter (Gradinaru et al., 2007). Alternatively, BAC transgenic mice expressing ChR2 protein under the control of the ChAT promoter (ChAT-ChR2-EYFP) have also been used, for example, to examine ACh/glutamate cotransmission in neurons thought to be strictly cholinergic (Ren et al., 2011; Zhao et al., 2011). However, a unique characteristic of the ChAT locus, also called cholinergic gene locus (Eiden, 1998), is that the entire open reading frame for the vesicular acetylcholine transporter $(V A C h T)$ lies within the intron between the first and second exons of the ChAT gene (Bejanin et al., 1994; Erickson et al., 1994; Roghani et al., 1994; Cervini et al., 1995; Naciff et al., 1997). Thus, the BAC containing the ChAT gene used to generate these mouse lines carries also the VAChT gene.

Importantly, increased expression of VAChT can alter ACh release. For example, in vitro overexpression of the VAChT in Xenopus neurons results in increased amplitude of miniature currents and in more synaptic vesicles containing ACh (Song et al., 1997). Moreover, a recent report indicates that a mouse line containing four copies of the ChAT-BAC driving the expression of GFP presents increased ACh release (Nagy and Aubert, 2012). However, the consequences of VAChT overexpression for cognitive functions are not yet understood. Because ChAT-ChR2EYFP mice have the potential to become widely used by the neuroscience community as a tool to determine the conse- 
quences of cholinergic activation for behavior manifestations, we determined the extent by which VAChT is overexpressed in this mouse line and whether overexpression of VAChT affects mouse behavior.

We report that ChAT-ChR2-EYFP mice have several extra copies of the VAChT gene and express increased VAChT mRNA and protein levels. ACh release is increased threefold in these mice. Importantly, we find that ChAT-ChR2-EYFP have increased physical endurance, consistent with increased cholinergic tone. In contrast with the improved motor function, cognitive tests demonstrated that increased expression of VAChT interferes with multiple domains of cognitive function.

\section{Materials and Methods}

Animals

All experiments were performed in compliance with the Canadian Council of Animal Care guidelines for the care and use of animals. The protocol was approved by the University of Western Ontario Institutional Animal Care and Use Committee (2008-127). All efforts were made to minimize the suffering of animals. ChAT-ChR2-EYFP mice [B6.Cg-Tg(ChatCOP4*H134R/EYFP)6Gfng/J; The Jackson Laboratory] and VGAT-ChR2EYFP mice [B6.Cg-Tg(Slc32a1-COP4*H134R/EYFP)8Gfng/J; The Jackson Laboratory] were described previously (Zhao et al., 2011) and were maintained as hemizygous. Control mice consisted of ChAT-ChR2-EYFP or VGAT-ChR2-EYFP negative littermates. Only male mice were used in these studies. Animals were housed in groups of two to four per cage in a temperature-controlled room with a 14/10 light/dark cycle. Food and water were provided ad libitum. Behavioral assessment started with less demanding (locomotor activity) to more demanding (depression and anxiety-like behavior, spatial memory in the Barnes maze, water maze, and then attention) tasks. Treadmill experiments were done after the water maze and before attention measurements. There was an interval of $3-5 \mathrm{~d}$ between distinct behavioral tasks. The experimenter was blind to the genotypes, and, in most behavioral tasks, software-based analysis was used to score mouse performance. All behavioral experiments were performed from 9:00 A.M. to 4:00 P.M. in the light cycle, except for the light/dark transition (always performed after 7:00 P.M.) and locomotor activity tests (performed from 5:00 P.M. to 9:00 P.M.; lights off at 7:00 P.M.).

\section{Immunofluorescence microscopy}

Mice were anesthetized using a ketamine (100 mg/kg)-xylene $(20 \mathrm{mg} / \mathrm{kg})$ solution and then killed by transcardial perfusion with $4 \%$ paraformaldehyde $(\mathrm{v} / \mathrm{v})$ in $1 \times$ PBS. Brains were harvested and placed in $4 \%$ paraformaldehyde in $1 \times \mathrm{PBS}$ at $4^{\circ} \mathrm{C}$ for $4 \mathrm{~h}$, and they were kept at $4^{\circ} \mathrm{C}$ until being sliced using a vibratome. Brain sections $(40 \mu \mathrm{m})$ were prepared, and free-floating sections in $1 \times$ PBS (one per well in a 24-well plate) were permeabilized with $0.4 \%$ Triton X-100 in $1 \times$ PBS for $1 \mathrm{~h}$. Nonspecific epitopes were blocked using a solution of $1 \times$ PBS $/ 0.4 \%$ Triton X-100 containing $0.1 \%$ glycine $(\mathrm{w} / \mathrm{v}), 0.1 \%$ lysine $(\mathrm{w} / \mathrm{v}), 1 \% \mathrm{BSA}(\mathrm{w} / \mathrm{v})$, and $1 \%$ normal donkey serum (w/v). Primary antibody (an FITC-conjugated goat polyclonal anti-GFP; catalog \#ab6662; Abcam) was incubated in blocking buffer overnight at $4^{\circ} \mathrm{C}$. Sections were then washed five times in $1 \times \mathrm{PBS} / 0.4 \%$ Triton X-100 (10 min each). Sections were mounted on slides and visualized using an Olympus IX81 laser-scanning microscope (FluoView) using an argon laser with parameters set for GFP. Images were taken using a $10 \times$ objective (numerical aperture 0.40 ) with the tile feature. Acquired images were then used to reconstruct the entire brain using the Olympus software.

\section{qPCR and Western blotting}

To genotype mice and to measure gene copies of VAChT, genomic DNA was extracted from tail-snip samples, and qPCR was used with the following primer pair: forward, 5'-GAGAGTACTTTGCCTGGGAGGA-3'; and reverse, 5'-GGCCACAGTAAGACCTCCCTTG-3'. The results were normalized to Stilp1 using the following primer pair: forward, $5^{\prime}$-ATGTATCTGA GCATGCCTCTG-3'; and reverse, $5^{\prime}$-ATTGCCCTTCTCCTTTAGCTC- ${ }^{\prime}$. To measure VAChT mRNA expression, total RNA was extracted using the Aurum Total RNA for fatty and fibrous tissue kit (Bio-Rad) according to the kit manual. cDNA synthesis and qPCR analysis were performed as described previously (Guzman et al., 2011). Immunoblotting was performed as described previously (Martins-Silva et al., 2011). The antibodies used were anti-VAChT (catalog \#139103; Synaptic Systems), anti-ChAT (catalog \#A144p; Millipore), anti-Synaptophysin (catalog \#S5768; Sigma-Aldrich), and anti-Actin (catalog \#ab49900; Abcam).

\section{ACh release}

ACh release from hippocampal brain slices was done as described previously (Guzman et al., 2011), by labeling slices with $\left[{ }^{3} \mathrm{H}\right]$ methyl-choline, before using $\mathrm{KCl}$ to stimulate release of labeled $\mathrm{ACh}$.

\section{Metabolic assessments}

Oxygen consumption, carbon dioxide production, respiratory exchange ratio (RER), food and water intake, and physical activity were simultaneously measured for young and adult mice by using the Comprehensive Lab Animal Monitoring System interfaced with Oxymax software (Columbus Instruments) essentially as described previously (Guzman et al., 2013). Mice were individually housed in the metabolic chambers maintained at $24 \pm 1{ }^{\circ} \mathrm{C}$ and given ad libitum access to powdered standard rodent chow and water. All the measurements were taken every $10 \mathrm{~min}$ for $24 \mathrm{~h} \mathrm{(12} \mathrm{h} \mathrm{light/12} \mathrm{h} \mathrm{dark)} \mathrm{after} \mathrm{a} 16 \mathrm{~h}$ habituation period in the individual metabolic chambers. Total activity, ambulatory activity, and sleep (periods of inactivity) were obtained using the Opto-M3 Activity Monitor and Oxymax software algorithms (Columbus Instruments) as described previously (Guzman et al., 2013).

\section{Glucose tolerance test}

Animals were fasted for $5 \mathrm{~h}$ and then received an intraperitoneal injection of $2 \mathrm{~g} / \mathrm{kg}$ glucose. Blood glucose levels were measured at 0 (baseline), 30, $60,90,120$, and $150 \mathrm{~min}$ after glucose injection. Glucose levels were determined in blood samples obtained from a tail snip using ACCUCHEK Advantage (Roche Diagnostics).

\section{Grip force}

Forelimb and hindlimb grip strength were assessed using a previously described protocol (Prado et al., 2006).

\section{Treadmill}

To test motor endurance, a rodent treadmill (IITC Life Sciences), with a grid behind the track that delivered a mild electric shock (15-20 V) when the mouse fell off, was used. Before testing, mice were trained for $4 \mathrm{~d}$ (3 $\mathrm{min}$ /day). On the first day, inclination was set to $5^{\circ}$. The inclination was increased by $5^{\circ}$ on each subsequent training day. The initial training speed was $8 \mathrm{~m} / \mathrm{min}$, and the treadmill was accelerated by $1 \mathrm{~m} / \mathrm{min}$, up to $9 \mathrm{~m} / \mathrm{min}$. In the second training session, the initial speed was $10 \mathrm{~m} / \mathrm{min}$ and was increased to $11 \mathrm{~m} / \mathrm{min}$, whereas on the third day and fourth days, the speed was maintained at $12 \mathrm{~m} / \mathrm{min}$. On the test day, the initial speed was set to $12 \mathrm{~m} / \mathrm{min}$, and the ramp angle was set to $20^{\circ}$. Speed was increased to $20 \mathrm{~m} / \mathrm{min}$ over the course of the first $15 \mathrm{~min}$ of testing, after which it remained constant, until the test was complete. The test ended when $60 \mathrm{~min}$ had elapsed or the mouse had reached exhaustion (Lund et al., 2010).

Elevated plus maze, forced swimming test, and tail suspension test Anxiety-like behavior was assessed using the elevated plus maze test, performed as described previously (Martins-Silva et al., 2011). Sessions were recorded and the video was analyzed using the ANY-Maze Software (Stoelting) to determine total time spent in the open and closed arms. Depressive-like behavior was assessed using the forced swim and tail suspension tests (Martyn et al., 2012). For the forced swim test, mice were placed in a $2 \mathrm{~L}$ beaker containing $1.8 \mathrm{~L}$ of $25-27^{\circ} \mathrm{C}$ water, for $6 \mathrm{~min}$. For the tail suspension test, mice were suspended from their tails for $5 \mathrm{~min}$, held in place by a strip of masking tape placed $\sim 1.5$ inches from the base of the tail. Sessions were recorded for both tests, and immobility time and episodes were assessed using the ANY-Maze Software. For the forced swim test, only data obtained after the initial $2 \mathrm{~min}$ of the test were used for the analysis. 


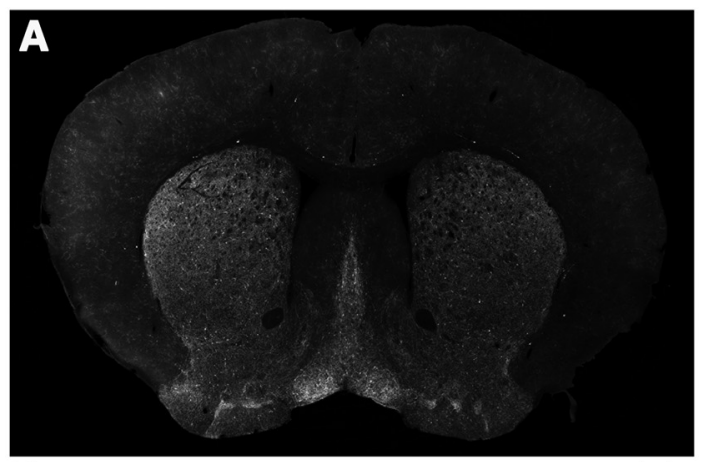

D
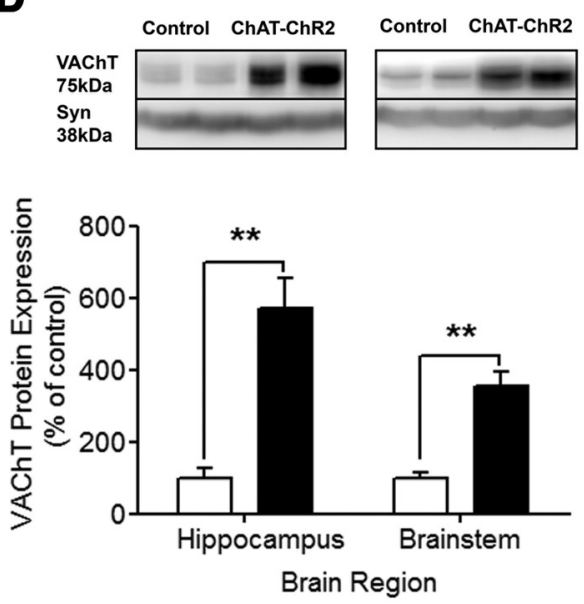

B

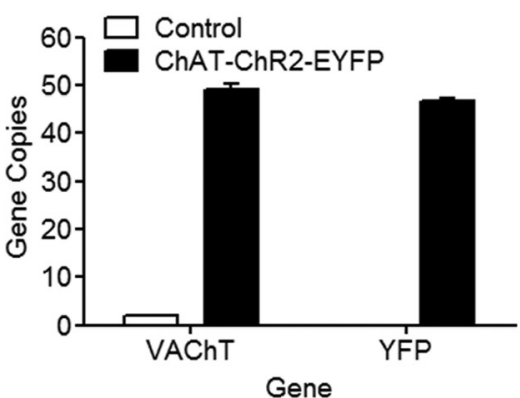

$\mathbf{E}$
C

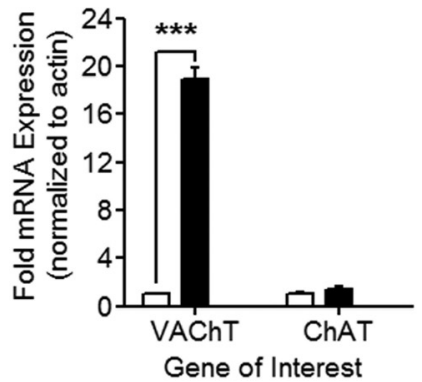

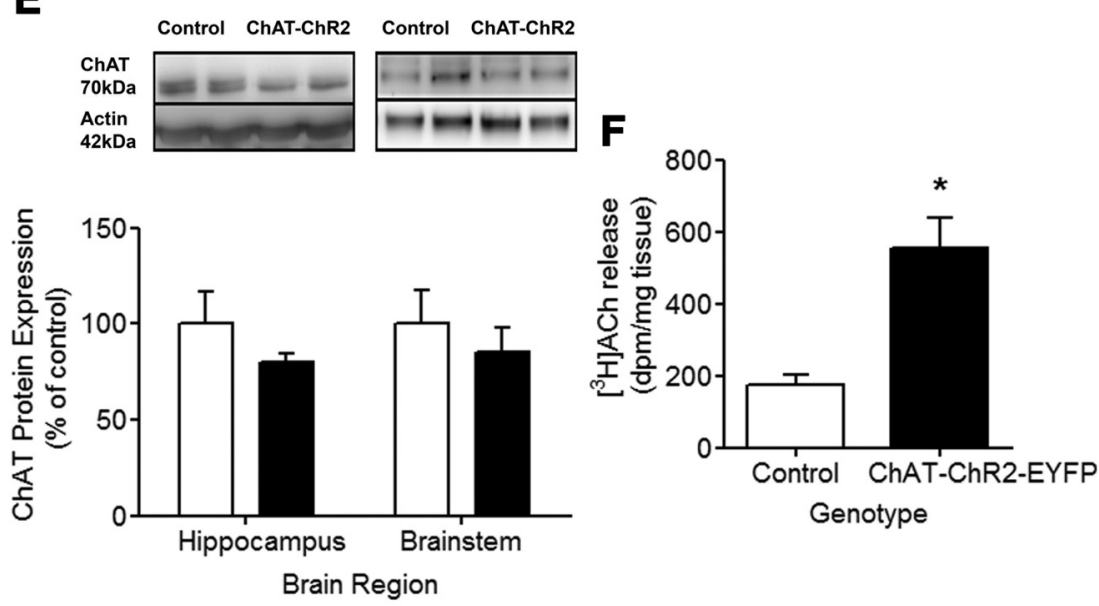

Figure 1. Overexpression of VAChT in ChAT-ChR2-EYFP mice. A, YFP expression in the CNS of ChAT-ChR2-EYFP mice $(n=3) . B, V A C h T$ and YFP gene copy numbers determined by genomic qPCR $(n=5)$. C, VAChT and ChAT mRNA expression in the striatum of wild-type and transgenic mice ( $n=6$ for both genotypes). $\boldsymbol{D}$, VAChT protein expression in the hippocampus and brainstem with representative immunoblots ( $n=3$ for both genotypes). $\boldsymbol{E}$, ChAT protein expression in the hippocampus and brainstem with representative immunoblots $(n=3$ for both genotypes). $\boldsymbol{F}$, Release of newly synthesized ACh in hippocampal slices ( $n=4$ for both genotypes). ${ }^{*} p<0.05,{ }^{* *} p<0.01,{ }^{* * *} p<0.001$.

\section{Rotarod}

The rotarod task was conducted as described previously to assess motor learning and acrobatic motor skill (Prado et al., 2006; de Castro et al., 2009a).

\section{Locomotor activity}

Spontaneous locomotor activity in a new environment to determine exploratory behavior was recorded using automated locomotor boxes essentially as described previously (Guzman et al., 2013).

\section{Spontaneous alternations $Y$-maze}

The spontaneous alternations Y-maze task to investigate working memory was performed using a symmetrical, three-armed Y-maze as described previously (de Castro et al., 2009a). All sessions were recorded. Both the order and the number of arm entries were recorded. A spontaneous alternation was counted when the mouse visited all three arms in a row without revisiting a previous arm.

\section{Barnes maze}

Barnes maze testing to determine spatial memory was performed as described previously (Patil et al., 2009; Martyn et al., 2012) using a white circular platform $(92 \mathrm{~cm}$ in diameter) with 20 equally spaced holes $(5 \mathrm{~cm}$ in diameter; $7.5 \mathrm{~cm}$ between holes), elevated $105 \mathrm{~cm}$ above the floor (San Diego Instruments), and spatial cues (posters, streamers, and plastic props) were placed around the maze. Briefly, animals were given four training trials a day for $4 \mathrm{~d}$, with a $15 \mathrm{~min}$ intertrial interval (ITI). On the fifth day, memory was assessed via a probe trial. The probe trial consisted of barring access to the target hole and assessing nose pokes to the holes within the target quadrant. Sessions were recorded and analyzed using the ANY-Maze Software.

\begin{tabular}{|c|c|}
\hline Genotype & Number of mice born \\
\hline$V A C h T^{w t / w t}$ & 2 \\
\hline$V A C h T^{w t / d e l}$ & 7 \\
\hline ChAT-ChR2-EYFP VAChT & 10 \\
\hline ChAT-ChR2-EYFP VAChT $T^{d e l / d e l}$ & 4 \\
\hline ChAT-ChR2-EYFP VAChT $T^{w t / w t}$ & 6 \\
\hline Total & 29 \\
\hline
\end{tabular}

ChAT-ChR2-EYFP mice were crossed to VACh $T^{d e l / w t}$ mice and offspring were then intercrossed. Genomic $\mathrm{PPCR}$ using primers that amplify the VACh ${ }^{d e l}$ allele was used to identify live VAChT ${ }^{d e l / d e l}$ mice containing the ChaT BAC.

\section{Morris water maze}

The spatial version of the Morris water maze (MWM) was conducted as described previously to investigate spatial memory (Vorhees and Williams, 2006; Martyn et al., 2012). Briefly, animals were given four training trials a day ( $90 \mathrm{~s}$ each) for $4 \mathrm{~d}$, with a $15 \mathrm{~min}$ ITI. If the mice did not find the platform after $90 \mathrm{~s}$ during the learning phase, they were gently directed to the platform. On the fifth day, memory was assessed via a probe trial $(60 \mathrm{~s})$, during which the platform is removed and time spent in the target quadrant is measured. The task was performed in a 1.5 -m-diameter pool with $25^{\circ} \mathrm{C}$ water. The platform was submerged $1 \mathrm{~cm}$ below the surface of the water, and spatial cues (posters, streamers, and plastic props) were distributed around the pool. Sessions were recorded and analyzed using the ANY-Maze Software.

Both the two-trial and cued variations of the MWM were performed as described previously (Vorhees and Williams, 2006). Briefly, for the two-trial variation, used to assess working or trialdependent learning and memory, mice were tested over the course of $8 \mathrm{~d}$. The mouse was first given a $90 \mathrm{~s}$ trial, and then after a $15 \mathrm{~s} \mathrm{ITI}$, the 
mouse was given a second trial with identical platform location and starting point. This was repeated with four unique starting location/ platform location combinations a day. As for the cued variation, used to assess goal-directed behavior, mice were tested for $2 \mathrm{~d}$ using novel platform and starting location combinations. For this variation, the platform was at water level and a cue was placed on it (a plastic block). Sessions were recorded for both tests and were analyzed using the ANY-Maze Software.

\section{Five-choice serial reaction time task}

Pretraining. The five-choice serial reaction time (5-CSRT) task is used to determine attention in mice (Robbins, 2002; Romberg et al., 2011). Mice were trained in the 5-CSRT in automated Bussey-Saksida Mouse Touch Screen Systems model 81426 (Campden Instruments Limited). Schedules were designed and data were collected using the ABET II Touch software v.2.15 (Lafayette Instruments). Before being trained on the 5-CSRT task, mice were first put through a pretraining program. This consisted of first habituating the mouse to the testing chamber with the lights off for $15 \mathrm{~min}$. The next day, the mouse was left in the chamber with the lights off for $20 \mathrm{~min}$. At this time, the reward tray was primed with strawberry milkshake (Saputo Dairy Products), and a tone was played when the mouse entered the reward tray. Whenever the mouse returned to the reward tray, it received a reward paired with the tone. This was repeated the next $2 \mathrm{~d}$ for $40 \mathrm{~min}$ sessions (phase 1).

The next training phase (phase 2) involved pairing the reward with presentation of the stimulus (flash of light in one of the five windows) on the touchscreen. The stimulus appeared randomly, and, after $30 \mathrm{~s}$, it was removed and a reward was given paired with a tone. If the mouse touched the screen while stimulus was displayed, it immediately received a reward. Once the mouse collected the reward, a new trial was initiated. This phase was repeated until the mouse completed 30 trials within 60 min (phase 2).

To further shape behavior, phase 3 involved displaying the stimulus randomly in one of the windows. The mouse had to touch the stimulus on the screen to receive a reward paired with a tone. There was no response to the mouse touching anything but the stimulus. Once again, this was repeated until the mouse completed 30 trials within 60 min. The next phase (phase 4) was identical to phase 3 except that the mouse had to initiate each trial by nose poking the reward tray. Criterion was 30 correct trials within $60 \mathrm{~min}$.

Finally, in the last pretraining phase (phase 5 ), the previous procedure was repeated, but if the mouse touched an incorrect screen, it received a $5 \mathrm{~s}$ timeout, during which the chamber light was turned on. The final phase had a stricter criterion, requiring the mice to perform 30 trials in $60 \mathrm{~min}$ with 23 correct responses in 2 consecutive days.

For the 5-CSRT training phase, mice were trained to respond to brief flashes of light pseudorandomly displayed in one of the five spatial locations on the touchscreen. Each trial was initiated after the mouse poked the magazine. In this phase, the stimulus was delivered after a variable 5-10 s delay (delay period), during which the animal was required to attend to the screen. In case the mouse prematurely touched the screen during this delay, the response was recorded as premature and the mouse was punished with a $10 \mathrm{~s}$ timeout. The stimulus duration was initially set to $4 \mathrm{~s}$, followed by a limited holding period of $5 \mathrm{~s}$, during which the stimulus was absent but the mouse could still respond to the location (holding period). Each session lasted 50 trials or $1 \mathrm{~h}$. Responses to the stimulus window during stimulus presence or the holding period were recorded as correct, whereas responses to any other window were recorded as

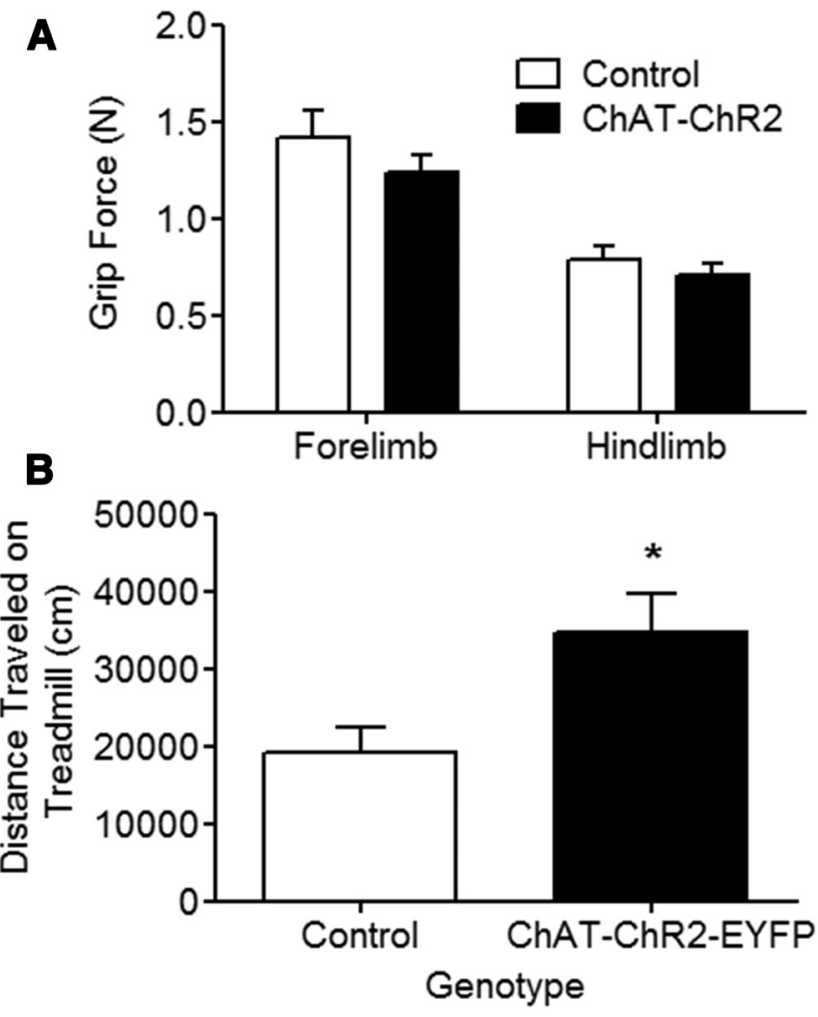

Figure 2. ChAT-ChR2-EYFP mice have increased physical endurance. $\boldsymbol{A}$, Grip force in wildtype and transgenic mice. $\boldsymbol{B}$, Treadmill analysis of physical endurance in wild-type and transgenic mice ( ${ }^{*} p<0.05, n=8$ for both genotypes).
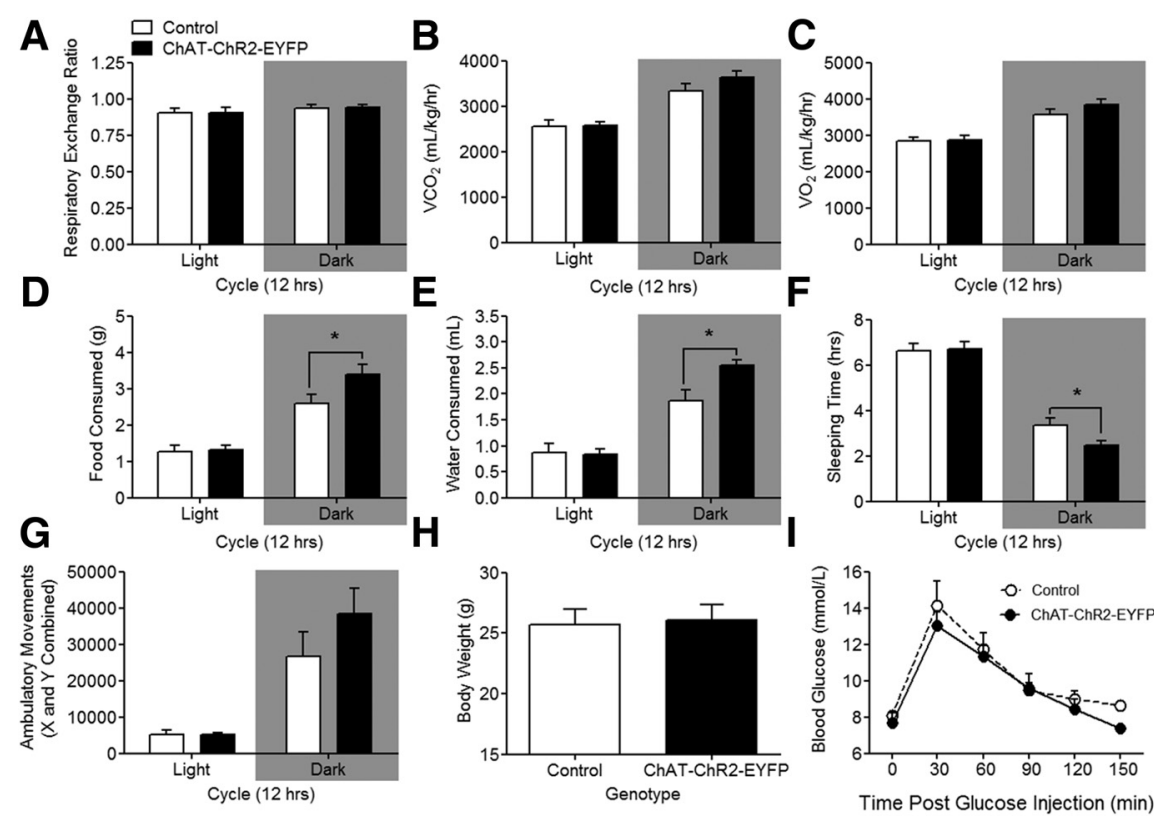

Figure 3. Metabolic analysis in ChAT-ChR2-EYFP mice. $A$, Respiratory exchange rate analysis. $\boldsymbol{B}, \mathrm{VCO}_{2}$ consumption. $\mathbf{C}_{1} \mathrm{VO}_{2}$. D Food consumption. $\boldsymbol{E}$, Water consumption. $\boldsymbol{F}$, Sleep time. $\boldsymbol{G}$, Home cage activity. $\boldsymbol{H}$, Body weight at time of analysis. $\boldsymbol{I}$, Glucose tolerance test. ${ }^{*} p<0.05, n=8$ for both genotypes.

incorrect. A correct choice was rewarded with a tone and food delivery. An incorrect response was punished with a $10 \mathrm{~s} \mathrm{timeout.} \mathrm{A} \mathrm{failure}$ to respond to any window either during stimulus display or the holding period was recorded as an omission, and the mouse was punished with a $10 \mathrm{~s}$ timeout. Perseverative responses to the screen after premature, correct, and incorrect choices were also recorded. Our initial 

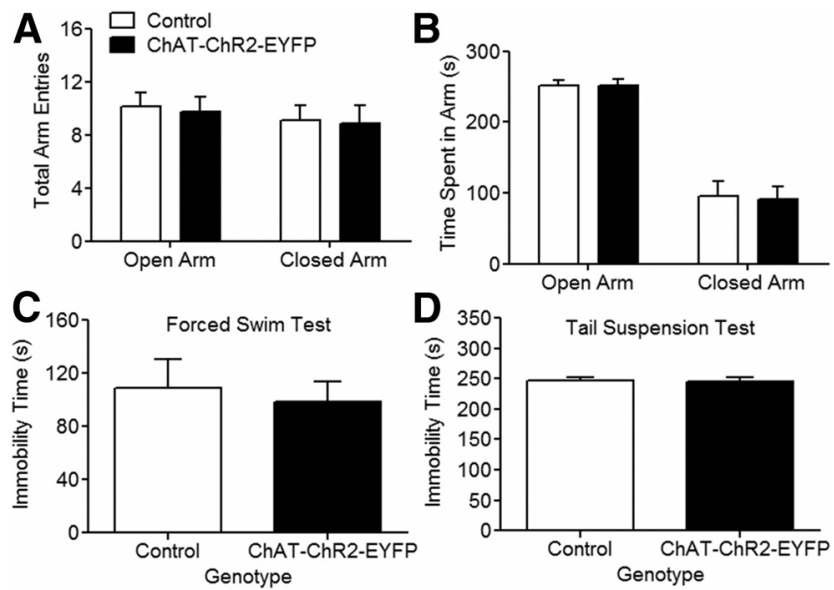

Figure 4. Assessment of anxiety and depressive-like behavior in ChAT-ChR2-EYFP mice. $\boldsymbol{A}$, Number of arm entries in the elevated plus maze. $\boldsymbol{B}$, Time spent in the open and closed arms. $\boldsymbol{C}$, Immobility time in the forced swimming test. $\boldsymbol{D}$, Immobility time in the tail suspension test ( $n=8$ for both genotypes).
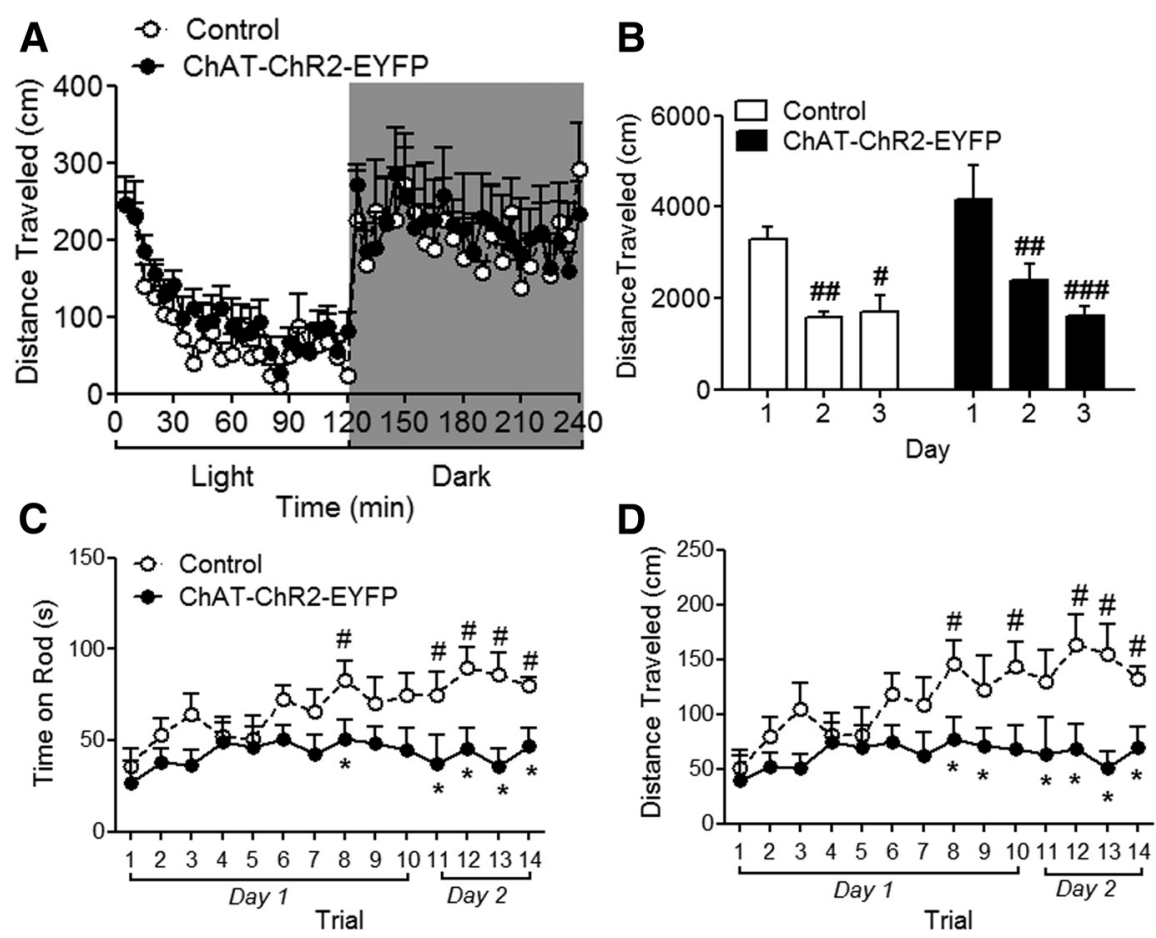

Figure 5. ChAT-ChR2-EYFP mice have normal locomotor activity but impaired motor learning. A, Locomotor activity of wild-type or ChAT-ChR2-EYFP mice during the light $(2 \mathrm{~h})$ and dark $(2 \mathrm{~h})$ activity periods in an open arm. The test was done from 5:00 P.M. to 9:00 P.M. B, Habituation in the open field. C, Acrobatic motor performance and motor learning in the rotarod. Time spent on the rod. $\boldsymbol{D}$, Distance traveled in the rotarod $\left({ }^{*} p<0.05\right.$, significant difference between genotypes; ${ }^{\#} p<0.05,{ }^{\# \#} p<0.01,{ }^{\# \# \#} p<0.001$, significant difference within genotype; $n=8$ for both genotypes).

goal was to have the performance of a mouse reaching criterion at $4 \mathrm{~s}$ stimulus duration $(80 \%$ accuracy, $20 \%$ omissions for 3 consecutive days) and reduce the stimulus duration to $2 \mathrm{~s}$. However, ChATChR2-EYFP BAC mice were not able to reach criterion at $4 \mathrm{~s}$ stimulus duration. Therefore, we used another training procedure, that is, the same cohort of mice was trained in a $16 \mathrm{~s}$ stimulus duration, and when they reached criterion, the stimulus duration was reduced to $8 \mathrm{~s}$. After reaching criterion with the $8 \mathrm{~s}$ stimulus, the mice were tested 2 more days, and the mean measures of those additional $2 \mathrm{~d}$ were used to assess baseline performance.

Probe trial. After finishing training at $8 \mathrm{~s}$ stimulus duration, mice were probed for attentional deficits in the following probe trial sched- ule: each mouse was tested over two sessions at a given stimulus duration (4 and $2 \mathrm{~s}$ ). Between each different stimulus duration, the mouse was returned to an $8 \mathrm{~s}$ stimulus duration for two baseline sessions. The order of the probe trial sessions was semirandomized using a Latin square method.

5-CSRT task measurements. On all 5-CSRT task sessions, accuracy was defined as the total number of correct responses divided by the number of correct and incorrect responses (touches to a wrong window while the correct stimulus was still displayed). Rate of omissions were the proportion of omitted responses to total trials. Response latency was the time for the mouse to touch the correct stimulus from its onset. Reward collection latency was the time for the mouse to return to the reward tray once it had touched the correct stimulus. A premature response was counted when the mouse touched one of the windows before stimulus onset. Finally, a perseverative response was any identical response that occurred after a correct, incorrect, or premature response.

\section{Statistical analyses}

Data are expressed as mean \pm SEM. SigmaStat 3.5 software was used for statistical analysis. Comparison between two experimental groups was done by Student's $t$ test or Mann-Whitney rank-sum test when the data did not follow a normal distribution. When several experimental groups or treatments were analyzed, two-way ANOVA or two-way repeated-measures (RM) ANOVA were used as required. When appropriate, a Tukey's HSD post hoc comparison test was used.

\section{Results}

Increased levels of VAChT in the ChAT-ChR2-EYFP BAC mice Immunofluorescence analysis confirmed previous findings that ChR2-EYFP is highly expressed in different areas of the brain (Zhao et al., 2011), including the striatum and basal forebrain (Fig. 1A), as well as interpeduncular nucleus and brainstem motor nuclei (data not shown). qPCR assays showed that ChAT-ChR2-EYFP mice contain $\sim 56$ copies of the VAChT gene and 54 copies of the YFP gene (Fig. $1 B$ ), suggesting that close to 50 copies of the ChAT-BAC were inserted in the mouse genome. RTqPCR data indicate that these additional copies of the VAChT gene are functional because VAChT mRNA was increased almost 20-fold in the striatum of ChAT-ChR2EYFP mice when compared with controls; importantly, expression of ChAT, as expected, was not changed (Fig. $1 C$ ). This increased VAChT mRNA level is consistent with the elevated copy number of ChATChR2-EYFP BAC. Expression of the VAChT protein is also increased (Fig. 1D) in this mouse line. In the hippocampus, there is a $550 \%$ increase in VAChT protein levels, whereas in the brainstem, VAChT levels are augmented by $350 \%$ when compared with control littermates (Fig. 1D). Expression of the ChAT protein was unaltered in both brain regions (Fig. $1 E$ ). Importantly, increased expression of VAChT protein had functional consequences, because ChAT-ChR2-EYFP BAC mice presented threefold to fourfold increase in the release of newly synthesized $\left[{ }^{3} \mathrm{H}\right] \mathrm{ACh}$ from hippocampal slices (Fig. $1 F$ ). Moreover, BAC transgenic expression of VAChT was able to rescue postnatal lethality 
attributable to VAChT elimination. We crossed ChAT-ChR2-EYFP with VAChT $T^{\text {del/wt }}$ [heterozygous VAChT knock-out (de Castro et al., 2009b)] mice and then intercrossed heterozygous littermates to obtain ChaT-ChR2-EYFP VAChT ${ }^{\text {del/del }}$. Screening of the offspring was done by qPCR of the VAChT del allele (de Castro et al., 2009b). Our data show that ChAT-ChR2-EYFP $V A C h T^{\text {del/del }}$ mice are viable and survive to adulthood (Table 1).

\section{ChAT-ChR2-EYFP mice have} improved motor endurance

To assess neuromuscular function in ChAT-ChR2-EYFP mice, both forelimb and hindlimb grip strength were measured, but there was no statistical difference between ChAT-ChR2-EYFP mice and control littermates (Fig. 2A). In contrast, ChATChR2-EYFP mice performed much better than wild-type controls in the treadmill. By using a protocol designed to determine physical fitness, we observed that ChATChR2-EYFP mice were able to run almost twice as much compared with control mice $\left(t_{(14)}=2.497, p=0.0256\right.$; Fig. $\left.2 B\right)$.

ChAT-ChR2-EYFP mice do not present gross alterations in metabolism

To investigate whether increased copy numbers of VAChT affects homeostasis, transgenic ChAT-ChR2-EYFP mice were assessed in metabolic cages. Transgenic mice had body weight statistically similar to controls $\left(t_{(14)}=0.6920, p=0.500\right.$; Fig. 3$)$. These mice presented similar metabolic profiles as controls, with no statistical differences in RER, in the light $\left(t_{(14)}=0.9898\right.$, $p=0.831)$ or the dark $\left(t_{(14)}=0.5414, p=\right.$ 0.702 ) cycles (Fig. $3 A$ ). They did not consume more $\mathrm{O}_{2}$ during the light cycle $\left(t_{(14)}=0.1897, p=0.8523\right)$ or dark cycle $\left(t_{(14)}=1.402, p=0.1828\right.$; Fig. 3B). Similar results were obtained for $\mathrm{CO}_{2}$ release during the light $\left(t_{(14)}=\right.$ $0.09952, p=0.9221)$ or dark $\left(t_{(14)}=1.462, p=0.1658\right)$ cycle (Fig. $3 C)$. Likewise, locomotor activity, sleep time, or blood glucose levels were not significantly altered in this transgenic mouse line (Fig. 3). Interestingly, ChAT-ChR2-EYFP mice consumed both more food and water during the dark cycle than control mice (food consumption, $t_{(14)}=2.212, p=0.0441$; water consumption, $t_{(14)}=2.878, p=$ 0.0122; Fig. $3 D, E)$.

\section{ChAT-ChR2-EYFP mice do not present anxiety or depression-like behavior}

We tested ChAT-ChR2-EYFP mice for anxiety using the elevated plus maze paradigm. These mice visited the open $\left(t_{(14)}=0.2304\right.$, $p=0.8211)$ or closed $\left(t_{(14)}=0.1365, p=0.8934\right)$ arms at rates statistically comparable with those observed in controls (Fig. 4A). In addition, they did not spend more time than controls in the open $\left(t_{(14)}=0.2304, p=0.8211\right)$ or closed $\left(t_{(14)}=0.1314, p=\right.$ 0.8973 ) arms (Fig. 4B). ChAT-ChR2-EYFP mice were also tested for depressive-like behavior using both the tail suspension and
B
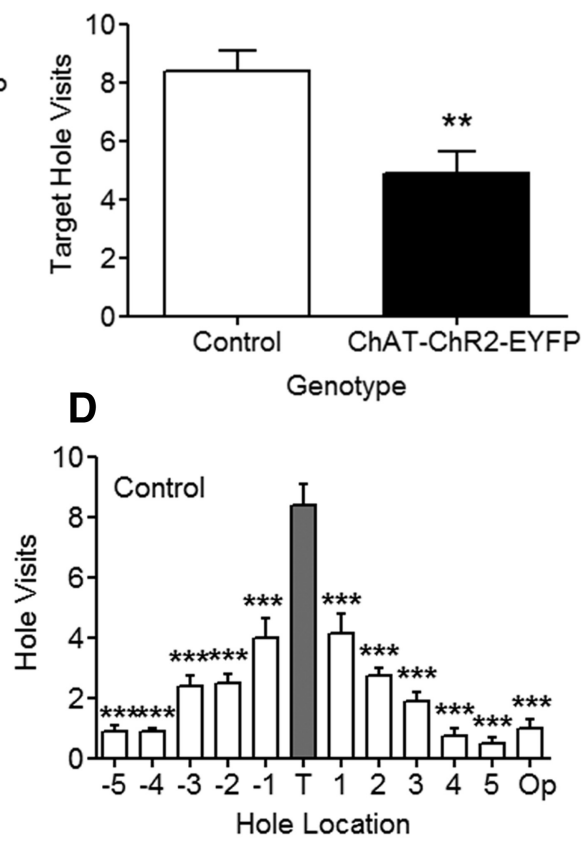

$\mathbf{F}$

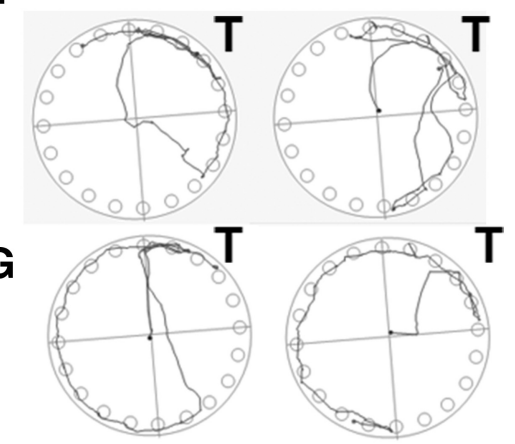

Figure 6. ChAT-ChR2-EYFP mice have spatial memory deficits in the Barnes maze. Mice were subject to the Barnes maze paradigm, and the average values of four 3-min trials per day are plotted. $\boldsymbol{A}$, Number of errors before finding the target hole. $\boldsymbol{B}$ , Numbers refer to the location of holes adjacent to the target hole. Op, 0pposite hole. $\boldsymbol{E}$, ChAT-ChR2-EYFP mice. $\boldsymbol{F}$ Representative path tracings for two control mice during the probe trial (target quadrant highlighted; T). G, Same as in $\boldsymbol{F}$ but for ChAT-ChR2-EYFP mice. ${ }^{*} p<0.05,{ }^{* *} p<0.01,{ }^{* * *} p<0.001, n=8$ for both genotypes.

forced swim tests and presented no statistical difference from wild-type controls (swim test, $t_{(14)}=0.4016, p=0.6941$; tail suspension, $t_{(14)}=0.04468, p=0.9650$; Fig. $3 C, D$, respectively).

\section{ChAT-ChR2-EYFP mice show normal locomotion but have} impaired motor learning

We assessed locomotor activity in ChAT-ChR2-EYFP mice using an automated novel open-field environment for $4 \mathrm{~h}: 2 \mathrm{~h}$ in the light and $2 \mathrm{~h}$ in the dark. No statistical differences in locomotor activity were observed between genotypes $\left(F_{(1,658)}=0.2468\right.$, $p=0.6271$; Fig. $5 A)$. There was no interaction between time $\times$ genotype $\left(F_{(47,658)}=0.4313, p=0.9997\right)$, with both genotypes significantly reducing their locomotor activity during the course of the test in the light phase $\left(F_{(47,658)}=9.725, p<\right.$ $0.0001)$. Moreover, habituation in the open field was not affected in ChAT-ChR2-EYFP mice [Fig. 5B; two-way RMANOVA shows a significant effect of day $\left(F_{(2,42)}=15.07, p<\right.$ $0.0001)$, no effect of genotype $\left(F_{(1,42)}=2.653, p=0.1108\right)$, and no interaction $\left.\left(F_{(2,42)}=0.880, p=0.4225\right)\right]$. 
A
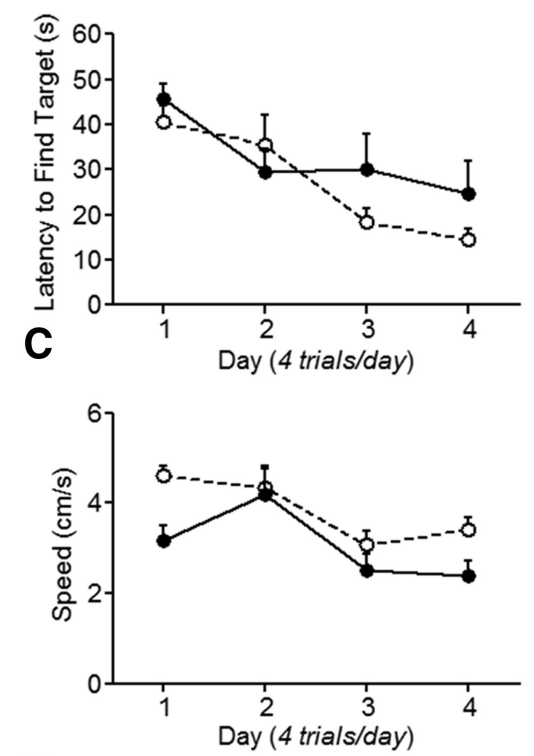

E

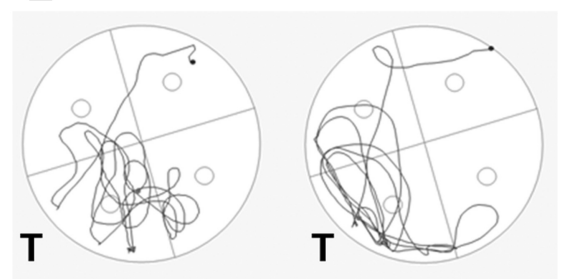

Control
B
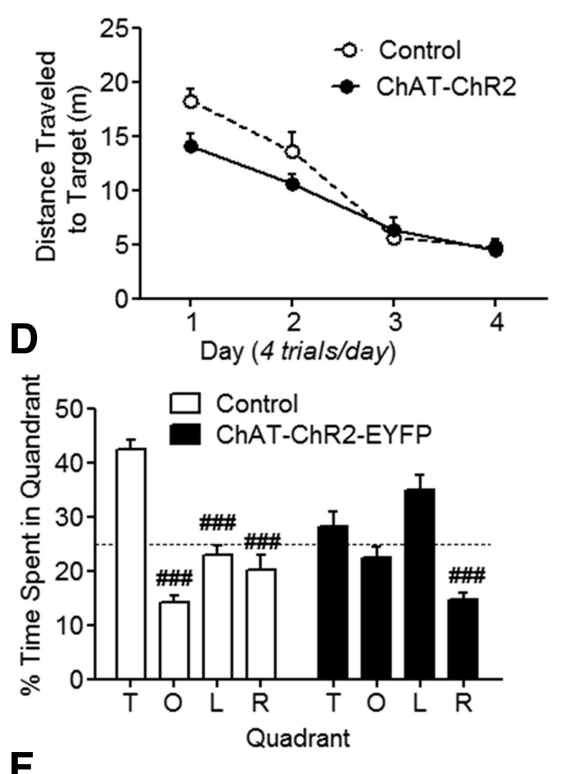

$\mathbf{F}$

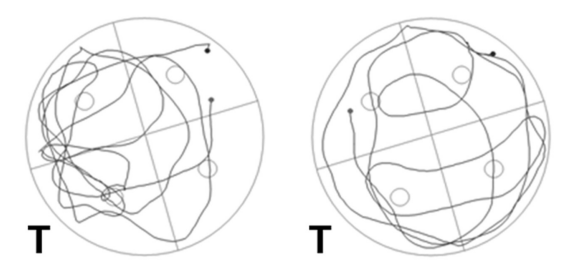

ChAT-ChR2-EYFP

Figure 7. ChAT-ChR2-EYFP mice have spatial memory deficits in the MWM. Mice were subject to the MWM paradigm, and the average values of four 90 -s trials per day are plotted. $\boldsymbol{A}$, Latency to find the platform. $\boldsymbol{B}$, Distance traveled to the platform. $\boldsymbol{C}$, Mouse speed. $\boldsymbol{D}$, Percentage time spent per quadrant was measured on day 5 in a $60 \mathrm{~s}$ probe trial with the platform removed. $\boldsymbol{E}$, Representative occupancy plots for two control mice. $\boldsymbol{F}$, Representative occupancy plots for two ChAT-ChR2-EYFP mice during the probe trial (T indicates the location of the target quadrant). ${ }^{\# \#} p<0.001$, significant difference within genotype, $n=8$ for both genotypes. L, Left; 0 , opposite; R, right; T, target.

Knowing that transgenic mice have increased endurance and no overt deficits in locomotor behavior, the accelerating rotarod task was used to assess motor learning. Surprisingly, the ChATChR2-EYFP mice failed to improve their performance in the rotarod, whereas wild-type control mice improved the time spent on the rotarod as well as distance traveled [Fig. 5C,D; two-way RM-ANOVA revealed main effect of genotype $\left(F_{(1,182)}=6.015\right.$, $p=0.0279)$ and trial $\left.\left(F_{(13,182)}=2.796, p=0.0012\right)\right]$. Post hoc analysis confirmed that the ChAT-ChR2-EYFP mice did not significantly improve their performance from their first trial.

\section{ChAT-ChR2-EYFP mice have impaired spatial memory}

To assess other forms of learning, we tested spatial learning and memory in the ChAT-ChR2-EYFP mice using the Barnes maze and MWM. During the acquisition phase of the Barnes maze, there were no statistical differences for the performance between the two genotypes. The two groups made a similar number of errors before reaching the target hole $\left(F_{(1,42)}=0.2685, p=\right.$ 0.6124; Fig. 6A). In contrast, during the probe trial, on day 5 , ChAT-ChR2-EYFP mice visited the target hole location significantly less than controls $\left(t_{(14)}=3.360, p=0.0047\right.$; Fig. $\left.6 B\right)$ and showed a significantly decreased preference for the target hole, as defined by the target hole preference index [target hole visits/ mean visits per hole (Holmes et al., 2002), $t_{(14)}=2.712, p=$ 0.0168; Fig. $6 C$ ]. Although both genotypes showed a significant effect of the hole location during the probe trial $\left(F_{(1,154)}=26.66, p=0.001\right)$, there was a significant effect of genotype $\left(F_{(1,154)}=11.29, p=0.047\right)$ and a significant genotype $\times$ hole location effect $\left(F_{(1,154)}=2.819, p=0.022\right)$. Post hoc analysis revealed that wild-type mice preferred the target hole, whereas ChAT-ChR2EYFP mice did not (Fig. 6D, E). Representative traces of two controls (Fig. $6 F$ ) and two ChAT-ChR2-EYFP mice (Fig. 6G) show the performance of the two genotypes in this task.

To further determine the mechanisms involved with potential spatial memory deficits, the MWM was used. Once again during the course of acquisition, the performance of ChAT-ChR2-EYFP mice was indistinguishable from that of controls in terms of latency to find the target $\left(F_{(1,42)}=\right.$ 0.8933, $p=0.3606)$ and the distance traveled to the target $\left(F_{(1,42)}=2.783\right.$, $p=0.1175$; Fig. $7 A-C)$. Mutants learned the location of the platform similar to control mice, confirming the observations using the Barnes maze. These results indicate that the ChAT-ChR2-EYFP mice do not have any gross sensorimotor deficits and were able to use the cues to learn the task. However, on the probe trial day, ChAT-ChR2-EYFP mice showed no preference for the target quadrant of the pool (Fig. 7D). The occupancy plots in the MWM on the probe trial show that the controls clearly remembered where the platform should be (Fig. 7E). In contrast, ChAT-ChR2-EYFP mice did not seem to retrieve this information during the probe trial (Fig. $7 F$ ).

\section{ChAT-ChR2-EYFP mice have deficiencies in} cue-directed memory

To assess cue-driven learning in these mice, the cued version of the MWM was used (Vorhees and Williams, 2006). There was a significant difference between genotypes $\left(F_{(1,14)}=5.262, p=\right.$ $0.0378)$ and a significant effect of day $\left(F_{(1,14)}=7.834, p=0.0142\right)$ in terms of latency to find the target (Fig. 8A). Post hoc analysis confirmed that control mice improved their performance from day 1 to day 2, whereas ChAT-ChR2-EYFP mice did not (Fig. $8 A$ ). There was a trend for ChAT-ChR2-EYFP mice to swim a greater distance to the target (Fig. $8 B$ ), but this failed to reach significance $\left(F_{(1,14)}=7.834, p=0.0861\right)$. A closer examination of the path traces revealed that ChAT-ChR2-EYFP mice do not seem to use the cue to find the target on the second day (Fig. $8 C, D$ ).

\section{ChAT-ChR2-EYFP have impaired working memory}

The above experiments suggest that ChAT-ChR2-EYFP mice can learn the spatial version of the MWM, but they have difficulty retrieving that memory trace. Moreover, these transgenic mice show impaired motor learning and cued-driven learning. These results suggest the possibility that chronically increased cholinergic tone disturbs distinct forms of information processing. To 
evaluate working memory, we first used spontaneous alternations in the Y-maze (de Castro et al., 2009a). In contrast to results obtained with littermate control mice, ChAT-ChR2-EYFP mice revisited the arms of the Y-maze more often, showing significantly less spontaneous alternations $\left(t_{(14)}=2.448, p=0.0293\right.$; Fig. $\left.9 A\right)$. The number of arm entries was not affected $\left(t_{(14)}=0.6031, p=0.5568\right.$; Fig. $9 B)$, nor was distance traveled $\left(t_{(14)}=\right.$ 0.5620, $p=0.5837$; data not shown). However, performance of ChAT-ChR2EYFP mice was above chance $(>50 \%)$ regarding alternations, suggesting that these mice had a partial dysfunction on their working memory. To exclude the possibility that the cognitive deficits observed could be related to the introduction of ChR2 or EYFP, we also tested VGAT-ChR2-EYFP and their littermate controls in the Y-maze alternation. qPCR analysis showed that these mice had $\sim 20$ copies of EYFP and therefore 20 copies of the ChR2 gene. Distinct from ChAT-ChR2-EYFP mice, VGAT-ChR2-EYFP mice did not differ statistically from their littermate controls in terms of either spontaneous alternations $\left(t_{(10)}=0.1914, p=0.8520\right.$; Fig. $\left.9 C\right)$ or number of arm entries $\left(t_{(10)}=1.562, p=\right.$ 0.1494; Fig. 9D).

To further probe working memory in ChAT-ChR2-EYFP mice, the two-trial variation of the MWM was used (Vorhees and Williams, 2006). In this variation of the task, mice must first find a novel platform location by chance and then, after a $10 \mathrm{~s}$ ITI, find it again. To analyze mouse performance on this task, we used the latency and distance savings ratio to standardize data (Varvel and Lichtman, 2002). These ratios were calculated by dividing the distance traveled, or latency on the first trial by that on the sum of the first and second trials. Values $>0.5$ indicate improvement from the first to the second trial. ChAT-ChR2-EYFP mice had significantly lower distance savings ratio $\left(t_{(14)}=2.501, p=0.0254\right)$ and latency savings ratio $\left(t_{(14)}=3.684, p=0.0025\right.$; Fig. $\left.9 E-H\right)$ than control mice. Together, these results indicate that ChAT-ChR2-EYFP mice have impaired working memory.

\section{ChAT-ChR2-EYFP mice have impaired attentional processing}

To determine whether ChAT-ChR2-EYFP mice may be affected in other cognitive domains that are sensitive to cholinergic tone and could contribute to the deficits we observed, we used the 5-CSRT task. During pretraining, transgenic mice did not differ from controls in terms of trials needed to achieve criterion [two-way RM-ANOVA; no effect of genotype $\left(F_{(1,48)}=0.6766, p=0.4268\right)$ and no effect of training phase $\left.\left(F_{(4,48)}=2.306, p=0.0717\right)\right]$. It should be noted that one mouse of each genotype never completed the pretraining and were not subjected to training in the 5-CSRT task. Our initial goal was to train mice first using a $4 \mathrm{~s}$ stimulus duration and then proceed to $2 \mathrm{~s}$ as described previously (Romberg et al., 2011). However, after 12 training sessions at $4 \mathrm{~s}$ stimulus duration, whereas all control mice reached criterion with an average of
B

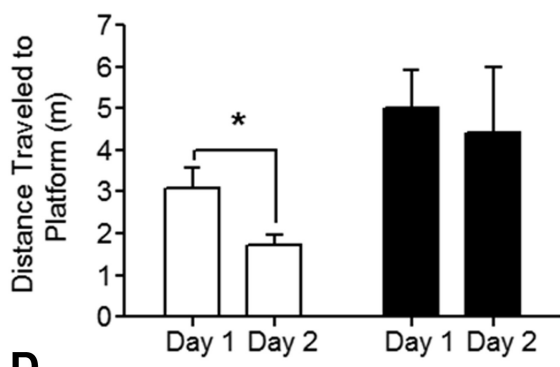

Day 1

Day 2

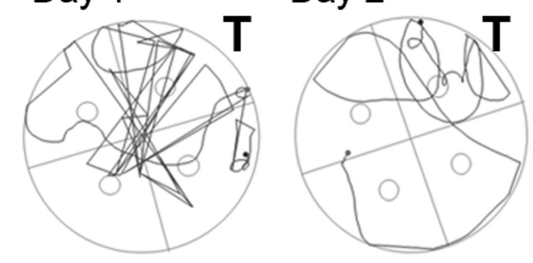

Day 2
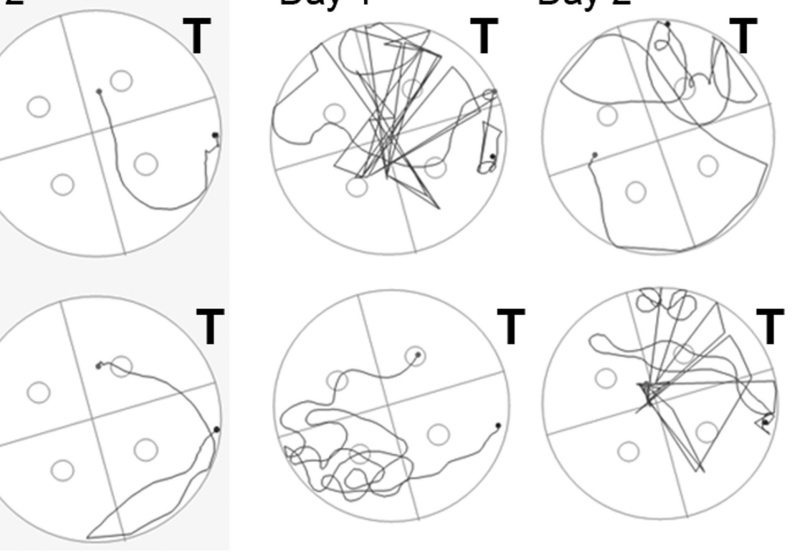

ChAT-ChR2-EYFP

Figure 8. ChAT-ChR2-EYFP mice have deficits in cue memory. Mice were subject to the cued version of the MWM in which they had to associate the platform with a cue. $\boldsymbol{A}$, Primary latency to find the platform. $\boldsymbol{B}$, Distance traveled to the platform. $\boldsymbol{C}$, Representative path tracings to the target of two control mice. D, Representative path tracings to the target of two ChAT-ChR2-EYFP mice. Traces are from the second trial on the first and second days of the experiment, with T indicating the location of the platform. The average of four 90 -s trials per day is plotted. ${ }^{*} p<0.05, n=8$ for both genotypes.

$10.28 \pm 1.23$ trials, all ChAT-ChR2-EYFP mice failed to acquire the task. Therefore, we increased the stimulus duration time (decreased the attentional demand) to $16 \mathrm{~s}$ and then $8 \mathrm{~s}$ to do the training. Probe trials were then performed with 4 and $2 \mathrm{~s}$ stimulus durations.

Under less demanding attentional conditions, ChAT-ChR2EYFP mice were able to acquire the task, reaching criteria at both stimulus durations (16 and $8 \mathrm{~s}$ ) in the same number of sessions as controls [two-way RM-ANOVA; no effect of genotype $\left(F_{(1,12)}=1.122, p=0.3103\right)$ and no effect of stimulus duration $\left.\left(F_{(1,12)}=2.492, p=0.1404\right)\right]$. However, during probe trials, ChATChR2-EYFP mice showed significant impairments in choice accuracy [two-way RM-ANOVA; main effect of genotype $\left(F_{(1,12)}=\right.$ 29.86, $p=0.0001)$ and no effect of stimulus duration $\left(F_{(1,12)}=\right.$ $0.6894, p=0.4226)$; Fig. $10 A]$, with post hoc analysis showing that the ChAT-ChR2-EYFP mice had impaired accuracy at both stimulus durations. The rate of omissions for ChAT-ChR2-EYFP mice was unaffected [two-way RM-ANOVA; no effect of genotype $\left(F_{(1,12)}=1.928, p=0.1902\right)$ and main effect of stimulus duration $\left(F_{(1,12)}=13.79, p=0.0030\right)$; Fig. 10B]. Additionally, ChAT-ChR2EYFP mice showed a significant increase in premature responses [two-way RM-ANOVA; main effect of genotype $\left(F_{(1,12)}=21.74\right.$, $p=0.0005)$ and main effect of stimulus duration $\left(F_{(1,12)}=7.657\right.$, $p=0.0171$ ); Fig. 10C]. Post hoc analysis revealed that the ChATChR2-EYFP mice had more premature responses at each stimulus duration. No change in perseverative responses was observed in ChAT-ChR2-EYFP mice [two-way RM-ANOVA; no effect of genotype $\left(F_{(1,12)}=0.05002, p=0.8268\right)$ and no effect of stimulus duration $\left(F_{(1,12)}=0.6894, p=0.4226\right)$; Fig. 

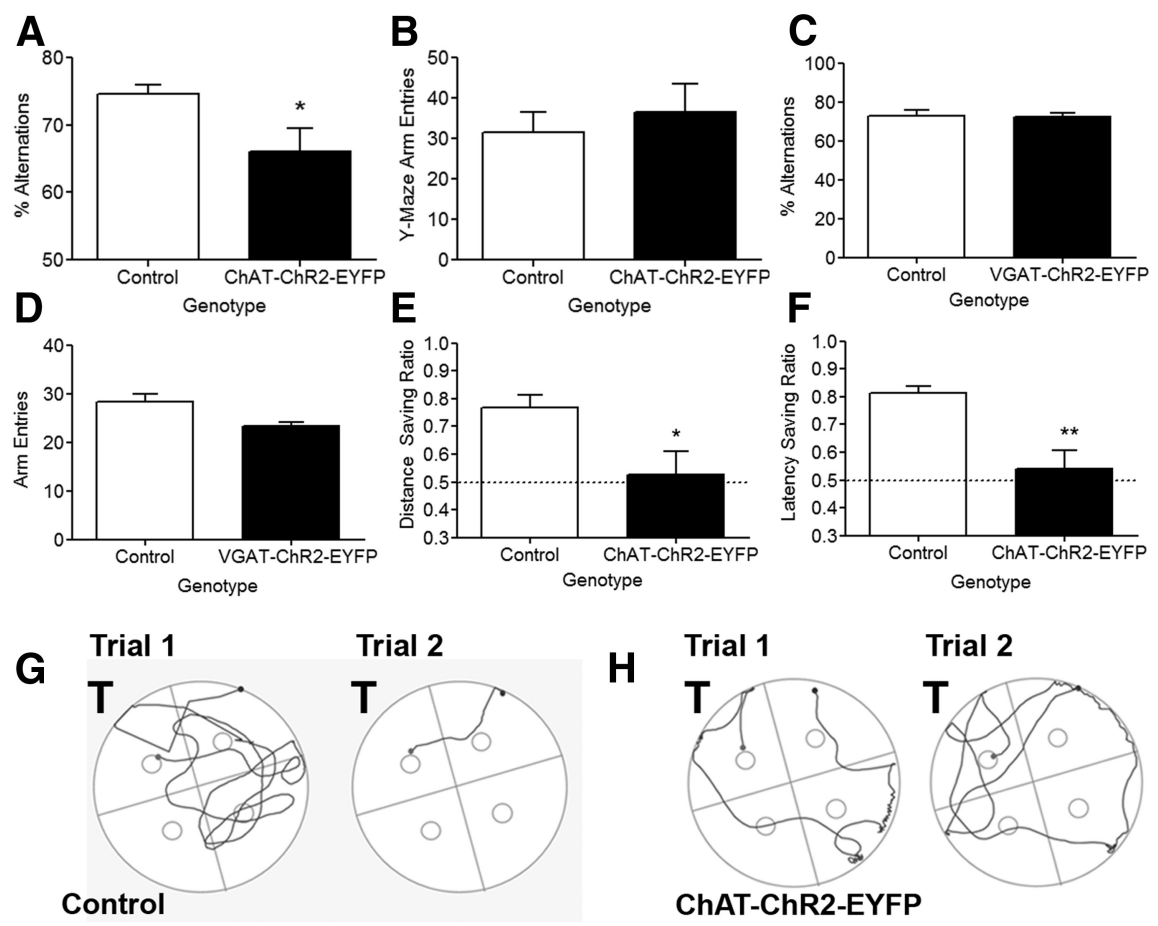

Figure 9. ChAT-ChR2-EYFP mice have deficits in working memory. $A$, Spontaneous alternations in the Y-maze were used to assess working memory for ChAT-ChR2-EYFP mice. B, Number of arms visited for ChAT-ChR2-EYFP mice $(n=8$ for both genotypes). C, Spontaneous alternations in the Y-maze for VGAT-ChR2-EYFP mice. D, Number of arms visited for VGAT-ChR2EYFP mice. $n=6$ for both genotypes. E, ChAT-ChR2-EYFP mice were subject to the two-trial MWM paradigm to further assess working memory. Savings ratios were calculated from the average of the first and second 90 s trials across all $4 \mathrm{~d}$ of the experiment. The graph shows the mean distance savings ratios. $\boldsymbol{F}$, Latency saving ratio. $\mathbf{G}$, Representative path tracings to the target for two control mice. $\boldsymbol{H}$, Representative path tracings to the target for two ChAT-ChR2-EYFP mice. Traces are from the first and second trials during the third day of the experiment. T indicates the location of the platform. ${ }^{*} p<0.05,{ }^{* *} p<0.01, n=8$ for both genotypes.

$10 D]$. Importantly, there were no differences between genotypes in terms of response latency [two-way RM-ANOVA; no effect of genotype $\left(F_{(1,12)}=1.570, p=0.2341\right)$ and no effect of stimulus duration $\left.\left(F_{(1,12)}=2.112, p=0.1718\right)\right]$ or reward collection latency [two-way RM-ANOVA; no effect of genotype $\left(F_{(1,12)}=1.082, p=0.3189\right)$ and no effect of stimulus duration $\left(F_{(1,12)}=0.001394, p=0.9708\right)$; Fig. $\left.10 E, F\right]$.

\section{Discussion}

Here we report an extensive characterization of the BAC transgenic ChAT-ChR2-EYFP mouse line and reveal two major findings. First, there are several extra copies of the VAChT gene in this mouse line, which led to increased levels of functional transporter, increased release of ACh, and improvement of physical endurance. Second, it seems that this chronic increase in cholinergic tone is deleterious in the CNS, disrupting several distinct cognitive domains. Interestingly, increase in VAChT mRNA expression was approximately fourfold higher than increase in protein expression. This result suggests the existence of translational or posttranslational mechanisms limiting the availability of the VAChT protein in cholinergic neurons.

Vesicular storage of ACh is a required step for ACh release (de Castro et al., 2009b), and decreased VAChT expression leads to motor and cognitive dysfunctions (Prado et al., 2006; Martyn et al., 2012). Specifically, reduction of VAChT levels affects grip strength and fatigue; VAChT knockdown homozygous mice, with $70 \%$ reduction in VAChT levels, are unable to run in a treadmill test (Prado et al., 2006). In agreement with these early results,
Trial 2

overexpression of the high-affinity choline transporter in motoneurons improves the performance of transgenic mice in the treadmill (Lund et al., 2010). The present results with ChAT-ChR2EYFP mice further support the notion that physical fitness is related to changes in cholinergic synaptic activity. Increased VAChT levels allowed transgenic mice to run farther than control nontransgenic littermates on the treadmill. However, it is unknown whether the increase in motor endurance results only from increased VAChT levels in motoneurons because, in this mouse line, VAChT is likely to be overexpressed in all cholinergic nerve endings. Decreased VAChT expression in the periphery has been shown to affect cardiac activity by distinct mechanisms (Lara et al., 2010; Rocha-Resende et al., 2012; Roy et al., 2012; Prado et al., 2013). Thus, ChAT-ChR2EYFP mice will be essential to determine whether increased VAChT expression can improve cardiovascular function.

Although a number of studies indicate that ACh is involved in the regulation of metabolic homeostasis (for review, see Picciotto et al., 2012), no significant difference between ChAT-ChR2-EYFP and wild-type littermates was observed when an extensive list of metabolic parameters was analyzed, including RER, the volume of oxygen produced $\left(\mathrm{VO}_{2}\right)$, the volume of carbon dioxide produced $\left(\mathrm{VCO}_{2}\right)$, body weight, sleeping time, ambulatory movement, and serum glucose. However, our data show that ChAT-ChR2-EYFP mice consume significantly more food and water during the dark period. It is possible that the small increase in food and water intake observed in these transgenic mice reflects the fact that, in the home-cage-like environment, they have a small tendency to be more active than controls. Surprisingly, ChAT-ChR2-EYFP mice did not show changes in locomotor activity in a novel environment, anxiety-like behavior, or depression-like behavior. To note, increased cholinergic transmission has been suggested to be pro-depressive (Janowsky et al., 1972; Overstreet et al., 1986; Overstreet, 1993; Fagergren et al., 2005). Moreover, antagonists of nicotinic and muscarinic receptors have antidepressant activity (Rabenstein et al., 2006; Andreasen and Redrobe, 2009). Because chronic increase in cholinergic tone may affect the expression of distinct receptors in specific brain regions, it is unlikely that all phenotypes described previously attributable to cholinesterase inhibition or dysfunction may be affected in ChAT-ChR2-EYFP mice.

Despite their increased motor endurance, ChAT-ChR2EYFP mice were unable to improve their performance in the rotarod, suggesting that increased cholinergic tone in the CNS is deleterious for learning an acrobatic skill. Previous experiments with mice presenting reduced levels of VAChT $(40 \%$ VAChT knockdown heterozygous mice) had indicated that motor learning depends on cholinergic tone (Prado et al., 2006; de Castro et al., 2009b). Together, these results suggest that either too much or too little ACh in the brain is detrimental for motor learning. 
We have also detected diminished performance of ChAT-ChR2-EYFP mice in two distinct tasks designed to measure spatial memory. In both the Barnes maze and MWM, ChAT-ChR2-EYFP mice present a specific deficit in the retrieval of information. In both tests, ChAT-ChR2EYFP mice were able to learn the task (location of the platform or the exit hole), as evidenced by their improved performance over the $4 \mathrm{~d}$ of training. However, in probe trials, ChAT-ChR2-EYFP mice performed poorly compared with their littermate controls in both tests. This phenotype may not be related only to spatial memory deficits, because these mice also presented impairments in the cued version of the MWM. Because ChATChR2-EYFP mice can improve their performance during the $4 \mathrm{~d}$ of training in the Barnes maze and MWM, it is unlikely that they present any gross sensory motor deficits that would preclude visualization of cues. Conversely, deficits in the cued version of the MWM suggest that increased cholinergic tone might interfere with the mouse's ability to recognize that the platform is the goal (cue detection). It has been reported that detection of signals depends on cholinergic neurotransmission (Sarter et al., 2005; Parikh et al., 2007). Therefore, the chronic excess of cholinergic tone may disrupt the transmission of salient information related to a cue, preventing these animals from using such information to guide them to their goal.

Working memory is a prefrontal cortical process that is modulated by cholinergic signaling (Croxson et al., 2011). There is strong evidence implicating cholinergic activity in enhancing discrimination of signal-to-noise in the prefrontal cortex (for review, see Hasselmo and Sarter, 2011), a role that is critical in regulating attention (Sarter et al., 2006; Parikh et al., 2007; Hasselmo and Sarter, 2011). However, the focus in the literature has been on hypocholinergic function (McGaughy et al., 2002; Dalley et al., 2004; Harati et al., 2008; Parikh et al., 2013), and to date, there has not been an evaluation of chronic cholinergic deregulation on attentive processing. Additionally, ACh has been shown to be important for feature binding, the process by which the brain processes specific features of an object and compile a unified picture of it (Botly and De Rosa, 2009). Interestingly ChAT-ChR2-EYFP mice showed inattentive behavior related to cholinergic dysregulation; however, they also showed increased premature responses in the 5-CSRT task, a behavior that has been shown to be regulated by serotonergic signaling (Fletcher et al., 2013; Humpston et al., 2013). ACh has been proposed to help filter sensory information by increasing persistent spiking in cortical neurons, compatible with its proposed role in facilitating cue detection (Hasselmo and Stern, 2006). Such a mechanism depends on background tonic level of ACh but also on the transient increase in cholinergic activity (Parikh et al., 2007). Whether tonic cholinergic activity in the
B
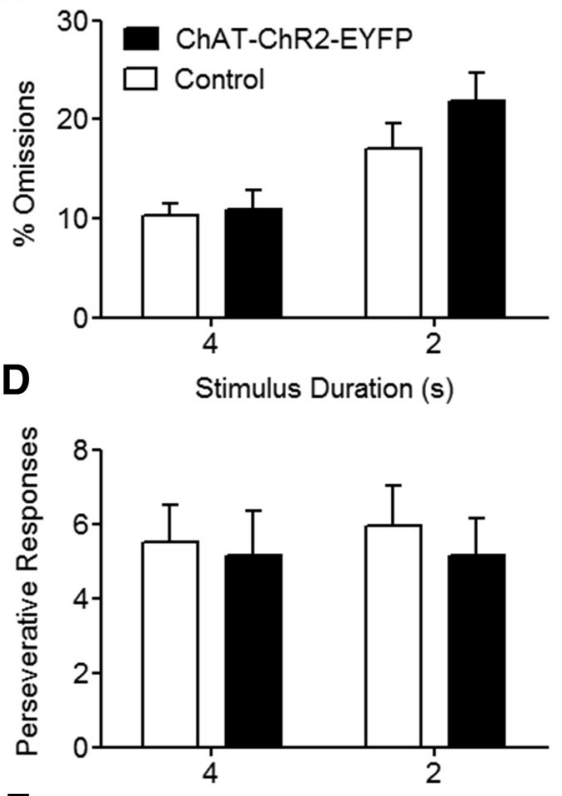

$\mathbf{F}$

Stimulus Duration (s)

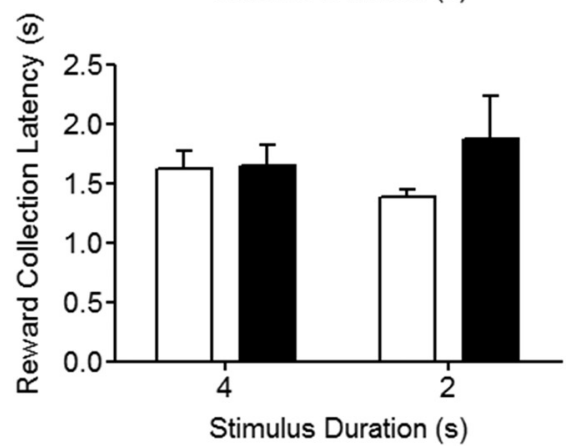

Figure 10. ChAT-ChR2-EYFP mice have deficits in attention. The 5-CSRT task was used to measure attention in the ChATChR2-EYFP mice. $\boldsymbol{A}$, Mean response accuracy during probe trial sessions. $\boldsymbol{B}$, Rate of omissions. To assess response patterns, both premature $(\boldsymbol{C})$ and perseverative $(\boldsymbol{D})$ responses were monitored during probe trials. $\boldsymbol{E}$, Mean response latency. $\boldsymbol{F}$, Mean reward collection latency. ${ }^{*} p<0.05,{ }^{* * *} p<0.001, n=7$ for both genotypes.

ChAT-ChR2-EYFP mice is so high that it precludes additional transient increases in cholinergic tone remains to be determined. However, the observation that ChAT-ChR2-EYFP mice have working memory and attention deficits suggests the possibility that multiple forms of information encoding are affected in these mice. Therefore, these experiments emphasize the importance of regulated $\mathrm{ACh}$ release in cognitive function.

The precise mechanism by which excessive release of ACh in ChAT-ChR2-EYFP mice affects memory is not yet clear. It is likely that cellular regulation of neuronal spiking (Hasselmo and Sarter, 2011) may be affected by chronically increased levels of extracellular ACh. Moreover, increased and sustained cholinergic tone may affect forebrain circuitries by changing the expression of receptors and the regulation of other neurochemical systems, leading to abnormal processing, encoding, or retrieval of information. The overall memory deficits observed in ChATChR2-EYFP mice suggest the need for specific temporal and spatial control of synaptic ACh levels for optimal cognitive performance.

In contrast with the worse performance of ChAT-ChR2EYFP mice in cognitive tasks, augmented cholinergic tone seems to improve physical fitness, suggesting that increasing cholinergic 
tone may be beneficial in the periphery. Whether increased cholinergic function will be beneficial in other parameters regulated by the autonomic nervous system, as well as for improving the activity of the cholinergic anti-inflammatory pathway, remains to be determined.

Given that we detect improvement physical endurance and decreased performance in a series of behavioral tasks that have been previously related to cholinergic functions, we have interpreted our results as a potential consequence of increased cholinergic tone. It should be noted that we cannot eliminate the possibility that the large number of copies of the BAC inserted in the mouse genome disrupted a specific gene locus that could both improve physical endurance and disrupt cognition, although this seems unlikely. Also, we cannot discard the possibility that the high copy number of ChR2 or YFP may have unexpected consequences. We attempted to test this possibility by using another mouse line with high copy number of ChR2 and YFP. The VGATChR2-EYFP mice, which have 20 copies of these genes, did not present impairments in working memory. These results support the argument that the effects observed in ChAT-ChR2-EYFP mice are related to cholinergic hyperfunction. Importantly, these altered phenotypes fundamentally differentiate ChAT-ChR2EYFP from control mice.

In short, our experiments indicate that ChAT-ChR2-EYFP mice overexpress VAChT and show important functional consequences, including unforeseen effects in cognitive processing. Because most studies using optogenetic control of cholinergic neurons have used mice expressing Cre or ChR2 that was inserted in the ChAT-BAC (Witten et al., 2010; Bell et al., 2011; Gu and Yakel, 2011; Nagode et al., 2011; Cachope et al., 2012; Kalmbach et al., 2012), it is important to be aware that VAChT overexpression may contribute to behavioral or cellular outputs. Therefore, novel approaches to control cholinergic neurons using optogenetics may be necessary. Inactivation of the VAChT gene in the ChAT-BAC is a possible alternative. However, ChAT-ChR2EYFP mice will be valuable to test current theories of cholinergic function and the consequences of overactive cholinergic signaling for information processing.

\section{References}

Andreasen JT, Redrobe JP (2009) Antidepressant-like effects of nicotine and mecamylamine in the mouse forced swim and tail suspension tests: role of strain, test and sex. Behav Pharmacol 20:286-295. CrossRef Medline

Bejanin S, Cervini R, Mallet J, Berrard S (1994) A unique gene organization for two cholinergic markers, choline acetyltransferase and a putative vesicular transporter of acetylcholine. J Biol Chem 269:21944-21947. Medline

Bell KA, Shim H, Chen CK, McQuiston AR (2011) Nicotinic excitatory postsynaptic potentials in hippocampal CA1 interneurons are predominantly mediated by nicotinic receptors that contain alpha4 and beta2 subunits. Neuropharmacology 61:1379-1388. CrossRef Medline

Botly LC, De Rosa E (2009) Cholinergic deafferentation of the neocortex using 192 IgG-saporin impairs feature binding in rats. J Neurosci 29: 4120-4130. CrossRef Medline

Cachope R, Mateo Y, Mathur BN, Irving J, Wang HL, Morales M, Lovinger DM, Cheer JF (2012) Selective activation of cholinergic interneurons enhances accumbal phasic dopamine release: setting the tone for reward processing. Cell Rep 2:33-41. CrossRef Medline

Cervini R, Houhou L, Pradat PF, Béjanin S, Mallet J, Berrard S (1995) Specific vesicular acetylcholine transporter promoters lie within the first intron of the rat choline acetyltransferase gene. J Biol Chem 270: 24654-24657. CrossRef Medline

Changeux JP (2010) Nicotine addiction and nicotinic receptors: lessons from genetically modified mice. Nat Rev Neurosci 11:389-401. CrossRef Medline

Croxson PL, Kyriazis DA, Baxter MG (2011) Cholinergic modulation of a specific memory function of prefrontal cortex. Nat Neurosci 14:15101512. CrossRef Medline

Dalley JW, Theobald DE, Bouger P, Chudasama Y, Cardinal RN, Robbins TW (2004) Cortical cholinergic function and deficits in visual attentional performance in rats following 192 IgG-saporin-induced lesions of the medial prefrontal cortex. Cereb Cortex 14:922-932. CrossRef Medline

de Castro BM, Pereira GS, Magalhães V, Rossato JI, De Jaeger X, MartinsSilva C, Leles B, Lima P, Gomez MV, Gainetdinov RR, Caron MG, Izquierdo I, Cammarota M, Prado VF, Prado MA (2009a) Reduced expression of the vesicular acetylcholine transporter causes learning deficits in mice. Genes Brain Behav 8:23-35. CrossRef Medline

de Castro BM, De Jaeger X, Martins-Silva C, Lima RD, Amaral E, Menezes C, Lima P, Neves CM, Pires RG, Gould TW, Welch I, Kushmerick C, Guatimosim C, Izquierdo I, Cammarota M, Rylett RJ, Gomez MV, Caron MG, Oppenheim RW, Prado MA, Prado VF (2009b) The vesicular acetylcholine transporter is required for neuromuscular development and function. Mol Cell Biol 29:5238-5250. CrossRef Medline

Eiden LE (1998) The cholinergic gene locus. J Neurochem 70:2227-2240. CrossRef Medline

Erickson JD, Varoqui H, Schäfer MK, Modi W, Diebler MF, Weihe E, Rand J, Eiden LE, Bonner TI, Usdin TB (1994) Functional identification of a vesicular acetylcholine transporter and its expression from a "cholinergic” gene locus. J Biol Chem 269:21929-21932. Medline

Fagergren P, Overstreet DH, Goiny M, Hurd YL (2005) Blunted response to cocaine in the Flinders hypercholinergic animal model of depression. Neuroscience 132:1159-1171. CrossRef Medline

Fletcher PJ, Soko AD, Higgins GA (2013) Impulsive action in the 5-choice serial reaction time test in 5- $\mathrm{HT}(2) \mathrm{c}$ receptor null mutant mice. Psychopharmacology 226:561-570. CrossRef Medline

Gradinaru V, Thompson KR, Zhang F, Mogri M, Kay K, Schneider MB, Deisseroth K (2007) Targeting and readout strategies for fast optical neural control in vitro and in vivo. J Neurosci 27:14231-14238. CrossRef Medline

Gu Z, Yakel JL (2011) Timing-dependent septal cholinergic induction of dynamic hippocampal synaptic plasticity. Neuron 71:155-165. CrossRef Medline

Gu Z, Lamb PW, Yakel JL (2012) Cholinergic coordination of presynaptic and postsynaptic activity induces timing-dependent hippocampal synaptic plasticity. J Neurosci 32:12337-12348. CrossRef Medline

Guzman MS, De Jaeger X, Raulic S, Souza IA, Li AX, Schmid S, Menon RS, Gainetdinov RR, Caron MG, Bartha R, Prado VF, Prado MA (2011) Elimination of the vesicular acetylcholine transporter in the striatum reveals regulation of behaviour by cholinergic-glutamatergic cotransmission. PLoS Biol 9:e1001194. CrossRef Medline

Guzman MS, De Jaeger X, Drangova M, Prado MA, Gros R, Prado VF (2013) Mice with selective elimination of striatal acetylcholine release are lean, show altered energy homeostasis and changed sleep/wake cycle. J Neurochem 124:658-669. CrossRef Medline

Harati H, Barbelivien A, Cosquer B, Majchrzak M, Cassel JC (2008) Selective cholinergic lesions in the rat nucleus basalis magnocellularis with limited damage in the medial septum specifically alter attention performance in the five-choice serial reaction time task. Neuroscience 153:72-83. CrossRef Medline

Hasselmo ME, Sarter M (2011) Modes and models of forebrain cholinergic neuromodulation of cognition. Neuropsychopharmacology 36:52-73. CrossRef Medline

Hasselmo ME, Stern CE (2006) Mechanisms underlying working memory for novel information. Trends Cogn Sci 10:487-493. CrossRef Medline

Holmes A, Wrenn CC, Harris AP, Thayer KE, Crawley JN (2002) Behavioral profiles of inbred strains on novel olfactory, spatial and emotional tests for reference memory in mice. Genes Brain Behav 1:55-69. CrossRef Medline

Humpston CS, Wood CM, Robinson ES (2013) Investigating the roles of different monoamine transmitters and impulse control using the 5-choice serial reaction time task. J Psychopharmacol 27:213-221. CrossRef Medline

Janowsky DS, el-Yousef MK, Davis JM, Sekerke HJ (1972) A cholinergicadrenergic hypothesis of mania and depression. Lancet 2:632-635. Medline

Kalmbach A, Hedrick T, Waters J (2012) Selective optogenetic stimulation of cholinergic axons in neocortex. J Neurophysiol 107:2008-2019. CrossRef Medline 
Lara A,Damasceno DD, Pires R, Gros R, Gomes ER, Gavioli M, Lima RF, Guimarães D, Lima P, Bueno CR Jr, Vasconcelos A, Roman-Campos D, Menezes CA, Sirvente RA, Salemi VM, Mady C, Caron MG, Ferreira AJ, Brum PC, Resende RR, et al (2010) Dysautonomia due to reduced cholinergic neurotransmission causes cardiac remodeling and heart failure. Mol Cell Biol 30:1746-1756. CrossRef Medline

Lund D, Ruggiero AM, Ferguson SM, Wright J, English BA, Reisz PA, Whitaker SM, Peltier AC, Blakely RD (2010) Motor neuron-specific overexpression of the presynaptic choline transporter: impact on motor endurance and evoked muscle activity. Neuroscience 171:1041-1053. CrossRef Medline

Martins-Silva C, De Jaeger X, Guzman MS, Lima RD, Santos MS, Kushmerick C, Gomez MV, Caron MG, Prado MA, Prado VF (2011) Novel strains of mice deficient for the vesicular acetylcholine transporter: insights on transcriptional regulation and control of locomotor behavior. PloS One 6:e17611. CrossRef Medline

Martyn AC, De Jaeger X, Magalhães AC, Kesarwani R, Gonçalves DF, Raulic S, Guzman MS, Jackson MF, Izquierdo I, Macdonald JF, Prado MA, Prado VF (2012) Elimination of the vesicular acetylcholine transporter in the forebrain causes hyperactivity and deficits in spatial memory and long-term potentiation. Proc Natl Acad Sci U S A 109:17651-17656. CrossRef Medline

McGaughy J, Dalley JW, Morrison CH, Everitt BJ, Robbins TW (2002) Selective behavioral and neurochemical effects of cholinergic lesions produced by intrabasalis infusions of 192 IgG-saporin on attentional performance in a five-choice serial reaction time task. J Neurosci 22:19051913. Medline

Naciff JM, Misawa H, Dedman JR (1997) Molecular characterization of the mouse vesicular acetylcholine transporter gene. Neuroreport 8:3467-3473. CrossRef Medline

Nagode DA, Tang AH, Karson MA, Klugmann M, Alger BE (2011) Optogenetic release of ACh induces rhythmic bursts of perisomatic IPSCs in hippocampus. PloS One 6:e27691. CrossRef Medline

Nagy PM, Aubert I (2012) Overexpression of the vesicular acetylcholine transporter increased acetylcholine release in the hippocampus. Neuroscience 218:1-11. CrossRef Medline

Overstreet DH (1993) The Flinders sensitive line rats: a genetic animal model of depression. Neurosci Biobehav Rev 17:51-68. CrossRef Medline

Overstreet DH, Janowsky DS, Gillin JC, Shiromani PJ, Sutin EL (1986) Stress-induced immobility in rats with cholinergic supersensitivity. Biol Psychiatry 21:657-664. CrossRef Medline

Parikh V, Kozak R, Martinez V, Sarter M (2007) Prefrontal acetylcholine release controls cue detection on multiple timescales. Neuron 56:141154. CrossRef Medline

Parikh V, St Peters M, Blakely RD, Sarter M (2013) The presynaptic choline transporter imposes limits on sustained cortical acetylcholine release and attention. J Neurosci 33:2326-2337. CrossRef Medline

Patel JC, Rossignol E, Rice ME, Machold RP (2012) Opposing regulation of dopaminergic activity and exploratory motor behavior by forebrain and brainstem cholinergic circuits. Nat Commun 3:1172. CrossRef Medline

Patil SS, Sunyer B, Höger H, Lubec G (2009) Evaluation of spatial memory of C57BL/6J and CD1 mice in the Barnes maze, the Multiple T-maze and in the Morris water maze. Behav Brain Res 198:58-68. CrossRef Medline

Picciotto MR, Higley MJ, Mineur YS (2012) Acetylcholine as a neuromodulator: cholinergic signaling shapes nervous system function and behavior. Neuron 76:116-129. CrossRef Medline

Prado VF, Martins-Silva C, de Castro BM, Lima RF, Barros DM, Amaral E, Ramsey AJ, Sotnikova TD, Ramirez MR, Kim HG, Rossato JI, Koenen J, Quan H, Cota VR, Moraes MF, Gomez MV, Guatimosim C, Wetsel WC, Kushmerick C, Pereira GS, et al. (2006) Mice deficient for the vesicular acetylcholine transporter are myasthenic and have deficits in object and social recognition. Neuron 51:601-612. CrossRef Medline

Prado VF, Roy A, Kolisnyk B, Gros R, Prado MA (2013) Regulation of cholinergic activity by the vesicular acetylcholine transporter. Biochem J 450: 265-274. CrossRef Medline

Rabenstein RL, Caldarone BJ, Picciotto MR (2006) The nicotinic antagonist mecamylamine has antidepressant-like effects in wild-type but not beta2or alpha7-nicotinic acetylcholine receptor subunit knockout mice. Psychopharmacology 189:395-401. CrossRef Medline

Ren J, Qin C, Hu F, Tan J, Qiu L, Zhao S, Feng G, Luo M (2011) Habenula "cholinergic" neurons co-release glutamate and acetylcholine and activate postsynaptic neurons via distinct transmission modes. Neuron 69: 445-452. CrossRef Medline

Robbins TW (2002) The 5-choice serial reaction time task: behavioural pharmacology and functional neurochemistry. Psychopharmacology 163:362-380. CrossRef Medline

Rocha-Resende C, Roy A, Resende R, Ladeira MS, Lara A, de Morais Gomes ER, Prado VF, Gros R, Guatimosim C, Prado MA, Guatimosim S (2012) Non-neuronal cholinergic machinery present in cardiomyocytes offsets hypertrophic signals. J Mol Cell Cardiol 53:206-216. CrossRef Medline

Roghani A, Feldman J, Kohan SA, Shirzadi A, Gundersen CB, Brecha N, Edwards RH (1994) Molecular cloning of a putative vesicular transporter for acetylcholine. Proc Natl Acad Sci U S A 91:10620-10624. CrossRef Medline

Romberg C, Mattson MP, Mughal MR, Bussey TJ, Saksida LM (2011) Impaired attention in the 3xTgAD mouse model of Alzheimer's disease: rescue by donepezil (Aricept). J Neurosci 31:3500-3507. CrossRef Medline

Roy A, Lara A, Guimarães D, Pires R, Gomes ER, Carter DE, Gomez MV, Guatimosim S, Prado VF, Prado MA, Gros R (2012) An analysis of the myocardial transcriptome in a mouse model of cardiac dysfunction with decreased cholinergic neurotransmission. PLoS One 7:e39997. CrossRef Medline

Sarter M, Hasselmo ME, Bruno JP, Givens B (2005) Unraveling the attentional functions of cortical cholinergic inputs: interactions between signal-driven and cognitive modulation of signal detection. Brain Res Brain Res Rev 48:98-111. CrossRef Medline

Sarter M, Gehring WJ, Kozak R (2006) More attention must be paid: the neurobiology of attentional effort. Brain Res Rev 51:145-160. CrossRef Medline

Song H, Ming G, Fon E, Bellocchio E, Edwards RH, Poo M (1997) Expression of a putative vesicular acetylcholine transporter facilitates quantal transmitter packaging. Neuron 18:815-826. CrossRef Medline

Varvel SA, Lichtman AH (2002) Evaluation of CB1 receptor knockout mice in the Morris water maze. J Pharmacol Exp Ther 301:915-924. CrossRef Medline

Vorhees CV, Williams MT (2006) Morris water maze: procedures for assessing spatial and related forms of learning and memory. Nat Protoc 1:848-858. CrossRef Medline

Wess J, Eglen RM, Gautam D (2007) Muscarinic acetylcholine receptors: mutant mice provide new insights for drug development. Nat Rev Drug Discov 6:721-733. CrossRef Medline

Witten IB, Lin SC, Brodsky M, Prakash R, Diester I, Anikeeva P, Gradinaru V, Ramakrishnan C, Deisseroth K (2010) Cholinergic interneurons control local circuit activity and cocaine conditioning. Science 330:1677-1681. CrossRef Medline

Zhao S, Ting JT, Atallah HE, Qiu L, Tan J, Gloss B, Augustine GJ, Deisseroth K, Luo M, Graybiel AM, Feng G (2011) Cell type-specific channelrhodopsin-2 transgenic mice for optogenetic dissection of neural circuitry function. Nat Methods 8:745-752. CrossRef Medline 